\title{
Article \\ Driftwood Biomass in Italy: Estimation and Characterization
}

\author{
Franco Cotana, Cinzia Buratti, Marco Barbanera *, Gianluca Cavalaglio, Daniele Foschini, \\ Andrea Nicolini and Anna Laura Pisello
}

\author{
CIRIAF-Interuniversity Research Center, University of Perugia, Perugia 67-06125, Italy; cotana@crbnet.it (F.C.); \\ cinzia.buratti@unipg.it (C.B.); cavalaglio@crbnet.it (G.C.); foschini@crbnet.it (D.F.); \\ andrea.nicolini@unipg.it (A.N.); anna.pisello@unipg.it (A.L.P.) \\ * Correspondence: barbanera@crbnet.it; Tel.: +39-075-585-3812 \\ Academic Editors: Francesco Asdrubali and Pietro Buzzini \\ Received: 20 June 2016; Accepted: 22 July 2016; Published: 29 July 2016
}

\begin{abstract}
In Italy, the accumulation of driftwood along the shore is a significant issue, especially for the coastal municipalities of the Central and Northern regions. The purpose of this study was to evaluate the distribution and availability of the coastal driftwood in Italy and its impacts, as well as analyzing its chemical-physical properties to evaluate possible employment in combustion applications. On the basis of a data gathering campaign for the period 2010-2014, about 60,000 tons of driftwood are reported to accumulate along the Italian shores every year. The two regions hardest-hit were Liguria and Veneto, with about 15,000 tons and 12,000 tons, respectively. Three sites were selected for driftwood sampling. The main issue deriving from chemical characterization was the high chlorine content (up to $2 \%$ on dry basis) and metal oxides in the ashes. Driftwood samples were then subjected to a natural washing cycle for 1 month; results revealed a significant drop in chlorine and metal oxides contents (up to 80\%) and a low decrease of the lower heating value (about $20 \%$ ). Furthermore, the percolated water was analyzed in terms of chemical oxygen demand (COD), showing values (up to $1100 \mathrm{mg} \mathrm{O}_{2} / \mathrm{L}$ ) above the Italian limits for discharges into surface waters.
\end{abstract}

Keywords: driftwood; seawater salt; biomass; washing; fouling; slagging

\section{Introduction}

Increased flooding is likely to be one of the most serious effects of climate change in Europe over the coming decades [1]. An increase in intensive short-term precipitation in most of Europe is likely to lead to an increased risk of flash floods, particularly in the Mediterranean and Eastern Europe. Intense precipitation originates a rapid and large increase in discharge in the channel network, frequently triggering slope instabilities—such as landslides and debris flows-during the same event. These colluvial processes, coupled to the fluvial dynamics, supply large volumes of both sediments and, in particular, large wood to the channels in forested catchments. When the fallen trees enter river channels and are transported downriver during high flows, they mainly accumulate in the dead water area of the stream, in nearby river structures, or are flushed directly into the sea [2]. Therefore, riverine driftwood can end up on coastal beaches, and the abundance of this kind of litter declines with the distance from a river mouth [3]. The amount of treefall and the capacity of the river transport determine the amount of driftwood washing into the sea. Furthermore, the patterns of abundance of riverine driftwood on coastal beaches are expected to coincide with the directions of coastal winds or water currents (Figure 1).

Coastal driftwood is of great concern to local authorities, because it is able to cause difficulties to an important economic sector, such as seaside tourism. In fact, driftwood deposited along the coast is unsightly and unwelcoming to tourists or beachgoers, resulting in lost tourism revenue. For these 
reasons, driftwood has to be removed from the beaches with huge costs for local authorities. The energy utilization of driftwood is limited, due to the high content of seawater salts that can produce dioxins and melting slag in the boiler during the combustion [4]. In particular, the formation of dioxins is reported when organic components are burned under uncontrolled conditions in the presence of chlorine [5].

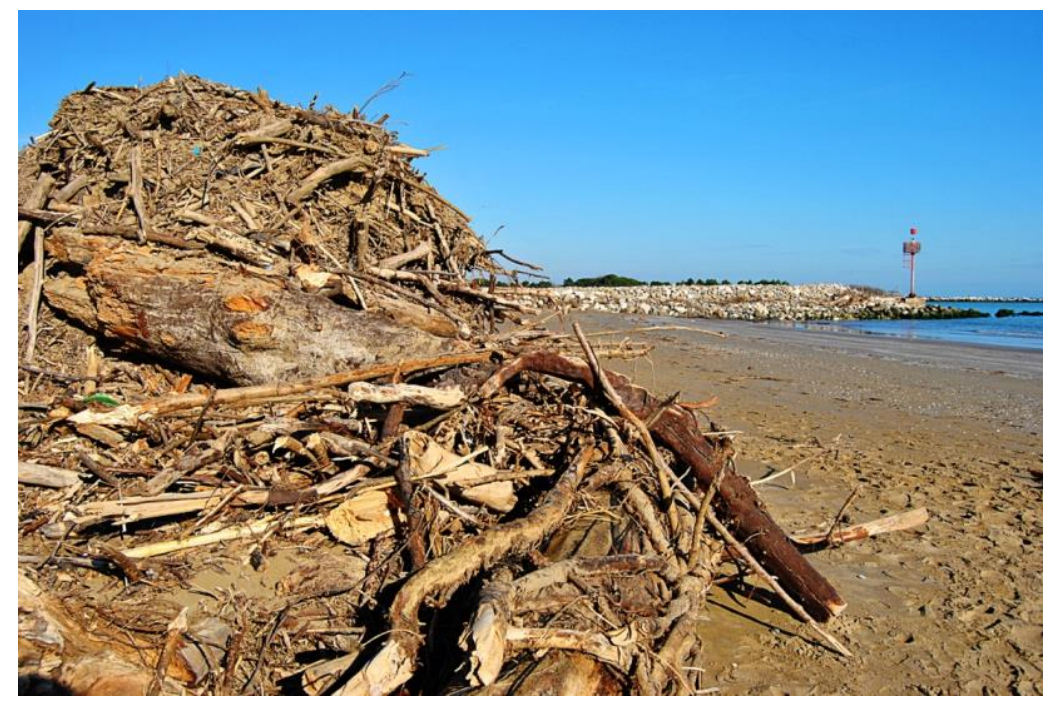

Figure 1. Driftwood accumulation at the mouth of the river Piave, Jesolo (Province of Venice).

In the literature, little information was found on availability and properties of coastal driftwood. Most studies focused on the large woody debris in the mountain forests and rivers or in the watershed [6]. Only Tsai et al. [7] evaluated the possibility of exploiting salt-laden driftwood for energy purposes in Taiwan. Main chemical and physical properties affecting the energy utilization were analyzed, concluding that the higher nitrogen content-compared to other biomass resources-requires a nitrogen oxides emission control system for biomass-to-heat facilities.

The aim of the present paper was firstly to carry out an assessment of the amounts and availability of driftwood stranding on Italian coastline. A field survey by applying structured questionnaires was also performed in order to collect data about the economic aspects of the actual driftwood management practices. Then, the most relevant chemical and physical properties of the residues for energy purposes were analyzed, and the effect of washing with rainwater was also tested.

\section{Materials and Methods}

\subsection{Data Gathering}

In order to collect a significant amount of data about the driftwood phenomenon, a questionnaire was developed.

The form was structured in four sections to collect a variety of information:

- Section 1-general information;

- Section 2-amount and type of driftwood;

- Section 3-treatment and disposal of driftwood;

- Section 4-economic aspects.

On the basis of the limited information available, cases of driftwood accumulation along the southern Italian coasts were not reported. Thus, the questionnaires were sent to each coastal municipality of central and northern Italy. As regards the amount of driftwood, the average value 
between 2010 and 2014 was requested from each municipality. More than 180 municipalities were asked, and about 100 answered; all of the answers were analyzed and the collected data were statistically aggregated at the regional level.

\subsection{Sampling Activity}

Following the data gathering, three sites were considered suitable for the sampling stage, in compliance with the criteria below:

- large quantities of driftwood on the shoreline have been reported in the last years;

- material collected on each site shall have a size range different from the others;

- geographical position.

Marinella di Sarzana (province of La Spezia), Jesolo (province of Venice), and San Benedetto del Tronto (province of Ascoli Piceno) were the sites chosen (Figure 2). Sampling activities consisted of the individuation of representative points and the collection of all the material in a $0.25 \mathrm{~m}^{2}$ area around them. Three samples per site were collected. In order to preserve the natural moisture content of driftwood, biomass was kept in sealed containers.

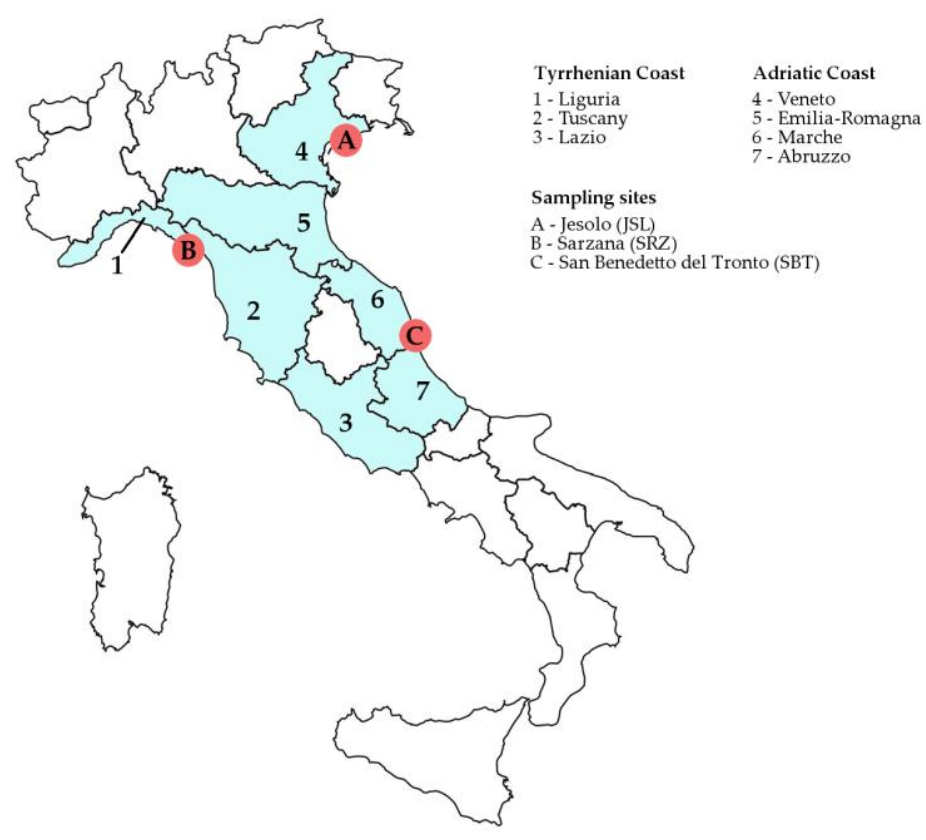

Figure 2. Map of the regions and the sites chosen for the survey.

\subsection{Characterization}

The samples were sieved through two sieves, and the material was classified in three classes:

- class $\mathrm{C} 1$, driftwood size greater than $50 \mathrm{~mm}$;

- $\quad$ class $\mathrm{C} 2$, driftwood size between 3.5 and $50 \mathrm{~mm}$;

- $\quad$ class C3, driftwood size less than $3.5 \mathrm{~mm}$.

Biomass was dried at $60{ }^{\circ} \mathrm{C}$ for $16 \mathrm{~h}$ in a climatic chamber MAZZALI Climatest. In order to quantify the sand content, the wood fraction was separated from the sand by wet sieving with a $2 \mathrm{~mm}$ sieve. Then, the organic fraction was completely separated from the sand by oxidation of the undersize fraction with $\mathrm{H}_{2} \mathrm{O}_{2}(30 \% \mathrm{w} / \mathrm{w}$ in water) [8]. Finally, the residue was washed in running water, dried at $105^{\circ} \mathrm{C}$, and weighed. 
Class $\mathrm{C} 1$ and class $\mathrm{C} 2$ samples were milled at $0.5 \mathrm{~mm}$ in two different laboratory mills: first in a RETSCH SM2000 cutting mill and later in a RETSCH ZM200 ultra centrifugal mill.

Thermogravimetric analysis were carried out on a LECO TGA701. Moisture, ash, volatile and fixed carbon contents were determined in compliance with UNI EN 14774-2, UNI EN 14775 and UNI EN 15148 standard methods [9,10]. Elemental analysis were performed using a LECO Truspec CHN analyzer. Carbon, hydrogen, and nitrogen contents were quantified by UNI EN 15104 standard method [11]. The driftwood gross calorific value was measured using a LECO AC350 Calorimeter. The lower heating value (LHV) was calculated as described in UNI EN 14918 standard method [12]. The determination of major elements of interest was carried out in compliance with UNI CEN/TS 15290/2006 and EN ISO 11885 [13,14]. Therefore, samples were firstly subjected to microwave acid digestion using a Milestone ETHOS One, and later the major elements content was determined by inductively coupled plasma emission spectrometer (ICP-OES) Perkin Elmer Optima2000DV. The total content of sulphur and chlorine was quantified following the UNI EN 15289 (method A). In addition, these analyses were carried out using an inductively coupled plasma emission spectrometer [15].

All analysis were performed in triplicate (standard deviations in all cases were $<5 \%$ ), with average data reported.

\subsection{Washing Stage}

Driftwood generally presents a high content of sulphur, chlorine, and major elements, and therefore it would not be suitable for most of the energy conversion processes. A natural rainfall washing method was developed in order to evaluate the reduction of the content of these elements over time. The experimental apparatus was fabricated by the Biomass Research Centre (CRB). It consists of two main parts: an outer shell made of durable plastic material and an inner tripod. In this way, two spaces are created for two different uses: the upper space, with a volume of $30 \mathrm{~L}$, is for loading material, while the under chamber, with a volume of $15 \mathrm{~L}$, is for washing water collection (Figure 3). The two zones are separated by a layer of porous fabric, and a tap is installed at the lowest point. Rainfall was monitored with a pluviometer.

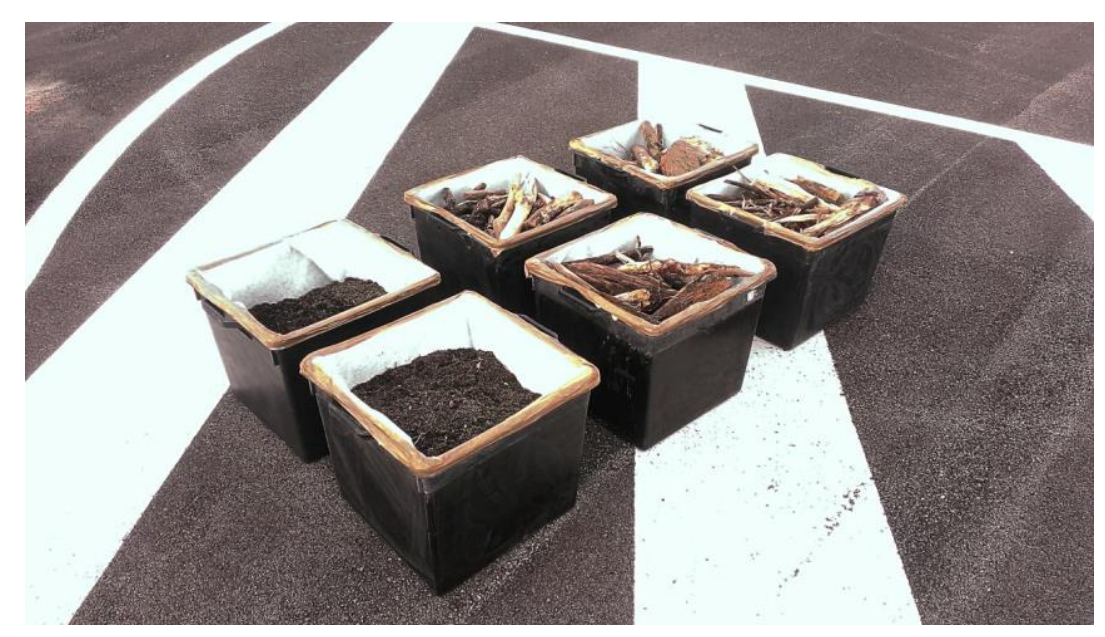

Figure 3. Samples undergone to the rainfall washing treatment.

The washing effect was evaluated on the basis of four indexes: alkali index (AI), fouling index (FI), slagging index (SI), and slag viscosity index (SVI) [16,17], according to the following equations:

$$
A I=\frac{1}{H H V} \times a s h \times\left(K_{2} \mathrm{O}+\mathrm{Na} a_{2} \mathrm{O}\right)_{a s h}
$$


where:

- HHV: higher heating value (MJ/kg);

- $\quad$ ash: ash content (\%);

- $\mathrm{K}_{2} \mathrm{O}: \mathrm{K}_{2} \mathrm{O}$ content in ash (\%);

- $\mathrm{Na}_{2} \mathrm{O}: \mathrm{Na}_{2} \mathrm{O}$ content in ash (\%);

$$
\mathrm{FI}=\frac{\mathrm{B}}{\mathrm{A}} \times\left(\mathrm{K}_{2} \mathrm{O}+\mathrm{Na}_{2} \mathrm{O}\right)_{a s h}
$$

where:

$$
\left.\frac{\mathrm{B}}{\mathrm{A}}=\frac{\left(\mathrm{K}_{2} \mathrm{O}+\mathrm{MgO}+\mathrm{Na}_{2} \mathrm{O}+\mathrm{CaO}+\mathrm{Fe}_{2} \mathrm{O}_{3}\right)_{\text {ash }}}{\left(\mathrm{SiO}_{2}+\mathrm{TiO}_{2}+\mathrm{Al}_{2} \mathrm{O}_{3}\right)_{\text {ash }}}\right)
$$

- $\mathrm{TiO}_{2}: \mathrm{TiO}_{2}$ content in ash (\%);

- $\mathrm{Al}_{2} \mathrm{O}_{3}: \mathrm{Al}_{2} \mathrm{O}_{3}$ content in ash (\%);

- $\mathrm{CaO}: \mathrm{CaO}$ content in ash (\%);

- $\mathrm{Fe}_{2} \mathrm{O}_{3}: \mathrm{Fe}_{2} \mathrm{O}_{3}$ content in ash (\%);

$$
\mathrm{SI}=\frac{\mathrm{B}}{\mathrm{A}} \times \mathrm{S}
$$

where:

- S: sulphur content (\%);

$$
\mathrm{SVI}=\frac{\left(\mathrm{SiO}_{2}\right)_{\text {ash }} \times 100}{\left(\mathrm{SiO}_{2}+\mathrm{MgO}+\mathrm{CaO}+\mathrm{Fe}_{2} \mathrm{O}_{3}\right)_{\text {ash }}}
$$

Some significant values of these indexes are summarized in Table 1.

Table 1. Significant values of AI, FI, SI, SVI indices.

\begin{tabular}{lll}
\hline Index & Limit & Effect \\
\hline \multirow{2}{*}{ Alkali Index (AI) } & $\mathrm{AI}>0.17 \mathrm{~kg} / \mathrm{GJ}$ & probable fouling \\
& $\mathrm{AI}>0.34 \mathrm{~kg} / \mathrm{GJ}$ & fouling is certain to occur \\
\hline \multirow{3}{*}{ Fouling Index (FI) } & $\mathrm{FI}<0.6$ & low fouling inclination \\
& $0.6<\mathrm{FI}<40$ & medium fouling inclination \\
& $\mathrm{FI}>40$ & high fouling inclination \\
\hline & $\mathrm{SI}<0.6$ & low slagging inclination \\
Slagging Index (SI) & $0.6<\mathrm{SI}<2.0$ & medium slagging inclination \\
& $2.0<\mathrm{SI}<2.6$ & high slagging inclination \\
& $\mathrm{SI}>2.6$ & extremely high slagging inclination \\
\hline & $\mathrm{SVI}>72$ & low slagging inclination \\
Slag Viscosity Index (SVI) & $65<\mathrm{SVI}>72$ & moderate slagging inclination \\
& $\mathrm{SVI}<65$ & high slagging inclination \\
\hline
\end{tabular}

Lastly, chemical oxygen demand (COD) of washing water was determined using a cuvette test method in the spectrophotometer AQUALYTIC AL450 and then compared to the regulatory limits accepted in Italy, summarized in Table $2[18,19]$.

Table 2. Italian regulatory limits for chemical oxygen demand (COD).

\begin{tabular}{ccc}
\hline & Discharge into Surface Water & Discharge on Land \\
\hline $\mathrm{COD}$ & $<160 \mathrm{mg} \mathrm{O}_{2} / \mathrm{L}$ & $<100 \mathrm{mg} \mathrm{O}_{2} / \mathrm{L}$ \\
\hline
\end{tabular}




\section{Results and Discussion}

\subsection{Driftwood Availability}

More than $60 \%$ of municipalities to which questionnaires were sent replied; the data provided were statistically aggregated at the regional level, as reported in Table 3.

Table 3. Results of data gathering on driftwood, Italian situation.

\begin{tabular}{cccccc}
\hline Region & Coastline $\mathbf{( k m )}$ & Tons per $\mathbf{k m}(\mathbf{t} / \mathbf{k m})$ & Total Tons $\mathbf{( t )}$ & Cost per Ton $(\boldsymbol{\epsilon} / \mathbf{t})$ & Total Cost $(\boldsymbol{\epsilon})$ \\
\hline Liguria & 266.88 & 57.59 & $15,370.72$ & 169.27 & $2,601,808.08$ \\
Tuscany & 275.55 & 9.17 & 2527.91 & 202.17 & $511,076.58$ \\
Lazio & 278.00 & 7.59 & 2110.65 & 134.97 & $284,870.24$ \\
Veneto & 139.07 & 90.61 & $12,601.74$ & 119.89 & $1,510,824.53$ \\
Emilia-Romagna & 114.92 & 102.68 & $11,799.99$ & 89.58 & $1,057,055.02$ \\
Marche & 163.44 & 72.37 & $11,827.99$ & 74.91 & $886,069.53$ \\
Abruzzo & 121.10 & 33.20 & 4020.62 & 111.30 & $447,510.05$ \\
Total & 1358.96 & & $60,259.62$ & & $7,299,214.03$ \\
\hline
\end{tabular}

Results show that more than 60,000 tons of driftwood accumulates every year on the central and northern Italian coastline. This phenomenon involves large treatment costs, due also to its influence on the local economies, strongly based on fishing and tourism. Local administrations' expenditure is estimated at around 7.3 million euros per year.

In particular, the Regions most affected by biomass accumulation on seashore are Liguria and Veneto, with about 15.3 and 12.6 thousands of tons per year, respectively.

In Italy, driftwood is classified as municipal solid waste, but no specific guidelines have yet been issued regarding the procedures for its collection and treatment; so, each municipality has its own management system, mostly based on the collection and landfill disposal or on-site incineration of driftwood. The first approach is characterized by high management costs: from the survey campaign, the average cost for driftwood management is estimated at $120 € /$ ton.

The main environmental issue is that landfilling not only takes up more and more valuable land space, but it also causes air, water, and soil pollution, discharging methane into the atmosphere and chemicals into the earth and groundwater. In particular, the European Commission adopted a legislative proposal and annex to review waste-related targets in the Landfill Directive 1999/31/EC as well as recycling and other waste-related targets in the EU Waste Framework Directive 2008/98/EC [20,21].

\subsection{Chemical-Physical Properties of Driftwood}

Driftwood collected in the three chosen sites had the size ranges and the sand contents shown in Table 4. Samples from Sarzana and Jesolo had medium and large dimensions and low sand content, while those from San Benedetto del Tronto had small dimensions and a sand content of about $50 \%$. Results of the characterization analysis are summarized in Tables 5-7.

Data highlight the differences between two groups of samples: SRZ.C1, SRZ.C2, JSL.C1, JSL.C2, on the one hand, and SRZ.C3 and SBT.C3, on the other hand.

The latter present high ash content (up to $24.35 \%$ ), low LHV (less than $14 \mathrm{MJ} / \mathrm{kg}$ ), C/N ratio lower than 30 in the case of SBT.C3, or 40 in the case of SRZ.C3, and considerable concentrations of some relevant major elements (calcium, sodium, magnesium, potassium, sulphur, and chlorine). Driftwood with these characteristics is not suitable for combustion. Samples of the first group have good LHV values (16.5-19.0 MJ/kg) and high C/N ratios (up to 85) in the case of SRZ.C1; therefore, they might seem potentially suitable for combustion. These values are in line with those of a typical biomass used as woodchip in an energy plant [22]. Thus, assuming the energy recovery of the $\mathrm{C} 1$ fraction of driftwood and an average moisture content of $40 \%$, the overall energy potential from driftwood in Liguria and Veneto regions is equal to about $166 \mathrm{TJ} /$ year and $144 \mathrm{TJ} /$ year, respectively. 
However high concentrations of major elements and considerable ash content were recorded. In the light of these data, it seems clear that contact with seawater and sand on the shore significantly influenced the salinity level and the ash content of the material.

Table 4. Sample characterization: size ranges and sand content.

\begin{tabular}{cccc}
\hline & SRZ.C1 & SRZ.C2 & SRZ.C3 \\
\hline Percentage & $84.87 \%$ & $13.51 \%$ & $1.62 \%$ \\
biomass & $99.23 \%$ & $96.12 \%$ & $83.75 \%$ \\
sand & $0.77 \%$ & $3.88 \%$ & $16.25 \%$ \\
\hline & SBT.C1 & SBT.C2 & SBT.C3 \\
\hline Percentage & $0.00 \%$ & $0.00 \%$ & $100.00 \%$ \\
biomass & - & - & $51.08 \%$ \\
sand & - & - & $48.92 \%$ \\
\hline & JSL.C1 & JSL.C2 & JSL.C3 \\
\hline Percentage & $92.44 \%$ & $7.56 \%$ & $0.00 \%$ \\
biomass & $99.88 \%$ & $99.41 \%$ & - \\
sand & $0.12 \%$ & $0.59 \%$ & - \\
\hline
\end{tabular}

Legend: SRZ = Sarzana; SBT $=$ San Benedetto del Tronto; JSL = Jesolo; $C 1=$ size $>50 \mathrm{~mm} ; C 2=50 \mathrm{~mm}>$ size $>$ $3.5 \mathrm{~mm} ; \mathrm{C} 3=$ size $<3.5 \mathrm{~mm}$.

Table 5. Sample characterization: results of thermogravimetric and calorimetric analysis. LHV: lower heating value.

\begin{tabular}{ccccc}
\hline Sample & Volatile (\% d.b.) & Ash (\% d.b.) & Fixed Carbon (\% d.b.) & LHV (MJ/kg) \\
\hline SRZ.C1 & 84.51 & 2.48 & 13.02 & 17.96 \\
SRZ.C2 & 83.73 & 3.71 & 12.55 & 16.96 \\
SRZ.C3 & 77.24 & 9.79 & 12.97 & 13.96 \\
JSL.C1 & 82.39 & 5.27 & 12.34 & 19.02 \\
JSL.C2 & 79.08 & 8.37 & 12.55 & 16.49 \\
SBT.C3 & 68.33 & 24.35 & 7.33 & 12.19 \\
\hline
\end{tabular}

Table 6. Sample characterization: elemental analysis, $\mathrm{Cl}$ and $\mathrm{S}$ analysis.

\begin{tabular}{cccccc}
\hline Sample & C (\% d.b.) & H (\% d.b.) & N (\% d.b.) & Cl (\% d.b.) & S (\% d.b.) \\
\hline SRZ.C1 & 47.78 & 6.05 & 0.56 & 0.72 & 0.06 \\
SRZ.C2 & 39.88 & 5.08 & 0.90 & 0.61 & 0.06 \\
SRZ.C3 & 18.00 & 2.56 & 0.49 & - & - \\
JSL.C1 & 46.46 & 5.91 & 0.61 & 1.82 & 0.39 \\
JSL.C2 & 44.60 & 5.59 & 0.70 & 2.04 & 0.17 \\
SBT.C3 & 31.38 & 3.87 & 1.29 & 1.10 & 0.47 \\
\hline
\end{tabular}

Table 7. Sample characterization: major elements analysis.

\begin{tabular}{ccccc}
\hline Sample & Na (\% d.b.) & Ca (\% d.b.) & Mg (\% d.b.) & K (\% d.b.) \\
\hline SRZ.C1 & 0.58 & 0.46 & 0.09 & 0.07 \\
SRZ.C2 & 0.58 & 0.88 & 0.10 & 0.06 \\
SRZ.C3 & 0.63 & 3.06 & 1.24 & 0.29 \\
JSL.C1 & 1.00 & 0.75 & 0.24 & 0.09 \\
JSL.C2 & 1.70 & 1.83 & 0.65 & 0.13 \\
SBT.C3 & 1.89 & 6.01 & 0.90 & 0.42 \\
\hline
\end{tabular}




\subsection{Effect of Washing on Driftwood Properties}

SRZ.C1 and JSL.C1 samples were subjected to natural rain washing. Test duration was 30 days, in which Perugia had $123 \mathrm{~mm}$ of rain.

At the end of the test, the material was air dried and then characterized in order to make a comparison between washed and unwashed biomass. It is important to mention that degradation by atmospheric agents decreased the dry matter content by around 30\%. Results are shown in Tables 8-10. Thermogravimetric analysis highlighted a decrease around $45 \%$ in ash content and a slight drop of LHV (about 10\%). Significant variations of C/N ratio were not found.

Table 8. Effect of washing: ash analysis, calorimetric analysis, and elemental analysis.

\begin{tabular}{cccccc}
\hline Sample & Ash (\% d.b.) & LHV (MJ/kg) & C (\% d.b.) & H (\% d.b.) & N (\% d.b.) \\
\hline JSL & 5.27 & 18.96 & 48.33 & 6.15 & 0.63 \\
JSL.Washed & 3.03 & 16.09 & 47.47 & 6.62 & 0.73 \\
SRZ & 2.48 & 17.96 & 50.13 & 6.35 & 0.59 \\
SRZ.Washed & 1.79 & 15.13 & 52.73 & 6.68 & 0.62 \\
\hline
\end{tabular}

Table 9. Effect of washing: major elements analysis, $\mathrm{Cl}$ and $\mathrm{S}$ analysis, reduction index (IR) calculation of Jesolo samples.

\begin{tabular}{|c|c|c|c|c|c|}
\hline & \multicolumn{2}{|c|}{ JSL } & \multicolumn{2}{|c|}{ JSL Washed } & \multirow{2}{*}{$\mathrm{IR}^{1}$} \\
\hline & \% (d.b.) & g (d.b.) & \% (d.b.) & g (d.b.) & \\
\hline $\mathrm{Al}$ & 1.18 & 1.85 & 0.85 & 0.76 & 58.65 \\
\hline $\mathrm{Ca}$ & 14.53 & 22.73 & 17.71 & 16.02 & 29.55 \\
\hline K & 1.82 & 2.85 & 1.66 & 1.44 & 49.37 \\
\hline $\mathrm{Mg}$ & 4.43 & 6.93 & 4.64 & 4.11 & 40.66 \\
\hline $\mathrm{Na}$ & 16.47 & 25.77 & 14.50 & 12.63 & 51.00 \\
\hline $\mathrm{Ti}$ & 0.17 & 0.26 & 0.09 & 0.09 & 67.03 \\
\hline $\mathrm{Cl}$ & 1.82 & 2.85 & 0.84 & 0.72 & 74.76 \\
\hline$S$ & 0.39 & 0.61 & 0.13 & 0.11 & 81.24 \\
\hline
\end{tabular}

Table 10. Effect of washing: major elements analysis, $\mathrm{Cl}$ and $\mathrm{S}$ analysis, reduction index calculation of Sarzana samples.

\begin{tabular}{|c|c|c|c|c|c|}
\hline & \multicolumn{2}{|c|}{ SRZ } & \multicolumn{2}{|c|}{ SRZ Washed } & \multirow{2}{*}{$\mathrm{IR}^{1}$} \\
\hline & $\%$ (d.b.) & g (d.b.) & $\%$ (d.b.) & g (d.b.) & \\
\hline $\mathrm{Al}$ & 1.237 & 0.942 & 2.528 & 0.481 & 48.91 \\
\hline $\mathrm{Ca}$ & 15.538 & 11.830 & 12.257 & 2.333 & 80.28 \\
\hline $\mathrm{K}$ & 1.891 & 1.440 & 2.707 & 0.515 & 64.21 \\
\hline $\mathrm{Mg}$ & 3.147 & 2.396 & 4.703 & 0.895 & 62.64 \\
\hline $\mathrm{Na}$ & 17.733 & 13.501 & 11.630 & 2.214 & 83.60 \\
\hline $\mathrm{Ti}$ & 0.114 & 0.087 & 0.226 & 0.043 & 50.44 \\
\hline $\mathrm{Cl}$ & 0.720 & 0.548 & 0.200 & 0.038 & 93.06 \\
\hline S & 0.060 & 0.046 & 0.010 & 0.002 & 95.83 \\
\hline
\end{tabular}

A remarkable reduction of almost all the major elements investigated was observed. In particular, the best reduction indexes (IR) were reported for chlorine and sulphur, with values up to $93.06 \%$ and $95.83 \%$, respectively. This is an important result because burning driftwood can produce polychlorinated dibenzo-p-dioxins and polychlorinated dibenzo-p-furans (PCDD/F). As shown by [5], the increase of fuel matrix chlorine from $0.04 \%$ to $0.8 \%$ can result in about a 100 -fold increase of $\mathrm{PCDD} / \mathrm{F}$. 
Values of alkali index, fouling index, slagging index, and slag viscosity index before and after the rainfall washing treatment are summarized in Table 11.

Table 11. Effect of washing: AI, FI, SI, SVI calculation.

\begin{tabular}{ccccc}
\hline & JSL & JSL Washed & SRZ & SRZ Washed \\
\hline $\mathrm{Al}_{2} \mathrm{O}_{3}(\%)$ & 2.231 & 1.599 & 2.338 & 4.778 \\
$\mathrm{CaO}(\%)$ & 20.335 & 24.791 & 21.753 & 17.160 \\
$\mathrm{Fe}_{2} \mathrm{O}_{3}(\%)$ & 0.752 & 2.840 & 0.413 & 1.966 \\
$\mathrm{~K}_{2} \mathrm{O}(\%)$ & 2.185 & 1.996 & 2.269 & 3.248 \\
$\mathrm{MgO}(\%)$ & 7.350 & 7.698 & 5.224 & 7.807 \\
$\mathrm{Na}_{2} \mathrm{O}(\%)$ & 22.229 & 19.583 & 23.940 & 15.701 \\
$\mathrm{SiO}_{2}(\%)$ & 5.965 & 7.539 & 3.606 & 32.303 \\
$\mathrm{TiO}_{2}(\%)$ & 0.276 & 0.157 & 0.190 & 0.377 \\
$\mathrm{AI}(\mathrm{kg} / \mathrm{GJ})$ & 0.68 & 0.39 & 0.36 & 0.074 \\
$\mathrm{FI}$ & 1.49 & 1.32 & 2.29 & 0.23 \\
$\mathrm{SI}$ & 0.025 & 0.008 & 0.005 & 0.0001 \\
$\mathrm{SVI}$ & 17.52 & 18.15 & 11.63 & 54.53 \\
\hline
\end{tabular}

After washing treatment, the indexes of the samples collected in Jesolo showed better values than those of untreated samples. Nevertheless, they still have values typical of a material not suitable for combustion process. In particular, AI and FI, with $0.39 \mathrm{~kg} / \mathrm{GJ}$ and 1.32, respectively, show an undesirable fouling inclination. This would cause deposits in the combustion chamber with a consequent decrease of efficiency. SI and SVI gave conflicting information on slagging inclination, with a good 0.008 and a poor 18.15, respectively. The best results were obtained for the samples collected in Sarzana: AI and FI showed a minimal fouling inclination, with values comparable to a commercial solid fuel. However, as for Jesolo, SI and SVI gave conflicting information on slagging inclination, with an excellent 0.0001 and a mediocre 18.15 , respectively.

In the literature, there are several studies concerned with leaching or washing of biomass [23], mainly regarding agricultural residues, such as sorghum [24], corn, and cotton stalks [25]. The main aim of the previous works was to tackle the deposition and corrosion problems during combustion by pretreating biomass via washing. However, only Jenkins et al. [26] evaluated the effectiveness of natural rain washing for the improvement of the combustion properties of biomass. They analysed rain-washed rice straw after $65 \mathrm{~mm}$ of cumulative rain fall, obtaining a reduction of the ash content equal to $4.2 \%$. Regarding chlorine and sulphur, the washing treatment led to a decrease of $92 \%$ and $33 \%$, respectively. Furthermore, the silica concentration of ash substantially increased (about 23\%), and appeared to be relatively inert, confirming the results observed in our study. In this regard, Gudka et al. [23] suggested that the solubility of $\mathrm{SiO}_{2}$ is improved with hot water.

\subsection{Washing Water Properties}

Results of characterization of the washing water are reported in Table 12.

Higher values were observed in the washing water of San Benedetto del Tronto, except for COD, iron, and silicon content. This is probably due to the smaller material size, which favoured the removal action of rain water.

However, in all examined cases, extremely high values of both chemical oxygen demand and major element concentrations were reported. Furthermore, the recorded salinity level was also remarkable and it could represent an environmental problem if the washing water is discharged into freshwater systems without any pretreatment. In fact, salinization of rivers and streams has lethal effects on aquatic life [27]; an electrical conductivity of $2 \mathrm{mS} / \mathrm{cm}$ can be suitable for drinking and irrigation but could have toxic effects on many freshwater insect species [28]. Therefore, the best solution could be to carry out the washing treatment along the coastline, in order to discharge the washing water directly 
into the sea. Otherwise, it would be necessary to install a proper washing water treatment, in order to avoid contamination of soil and groundwater.

Table 12. Characterization of washing water.

\begin{tabular}{cccc}
\hline & JSL Water & SRZ Water & SBT Water \\
\hline $\mathrm{COD}\left(\mathrm{mg} \mathrm{O}_{2} / \mathrm{L}\right)$ & 1091 & 995 & 770 \\
$\mathrm{pH}$ & 6.63 & 6.15 & 7.22 \\
Salinity (mS/cm) & 2.97 & 1.42 & 4.85 \\
$\mathrm{Al}(\mathrm{mg} / \mathrm{kg} \mathrm{d.b.})$ & 5.015 & 12.988 & 14.515 \\
$\mathrm{Ca}(\mathrm{mg} / \mathrm{kg}$ d.b. $)$ & 159.818 & 117.128 & 289.200 \\
$\mathrm{Fe}(\mathrm{mg} / \mathrm{kg}$ d.b. $)$ & 1.400 & 0.379 & 0.157 \\
$\mathrm{~K}(\mathrm{mg} / \mathrm{kg}$ d.b.) & 134.478 & 75.528 & 202.302 \\
$\mathrm{Mg}(\mathrm{mg} / \mathrm{kg}$ d.b. $)$ & 175.787 & 59.716 & 430.291 \\
$\mathrm{Na}(\mathrm{mg} / \mathrm{kg}$ d.b. $)$ & 2022.626 & 678.729 & 3655.805 \\
$\mathrm{Si}(\mathrm{mg} / \mathrm{kg}$ d.b.) & 0.238 & 0.319 & - \\
$\mathrm{Ti}(\mathrm{mg} / \mathrm{kg}$ d.b. $)$ & 0.531 & 0.406 & 0.604 \\
\hline
\end{tabular}

\section{Conclusions}

This study evaluates the recoverable amount of driftwood—an abundant and low-cost source of woody biomass in Italy-from the survey of coastal municipalities of the Northern and Central regions. The phenomenon of stranded driftwood generates very significant amounts of material that must be removed (about 60,000 tons) in order to guarantee the availability of the beach for human activities. The current management practices generate significant environmental issues. Due to the presence of other mixed material (sand, plastics, and other marine litter) and the high salt content, driftwood is not directly suitable for economic exploitation, but is generally considered as a municipal waste and is disposed of in landfill with high associated costs (about $120 € /$ ton).

To support the development and deployment of alternative thermochemical strategies for driftwood management, samples from three sites were collected and analyzed for their physical and chemical composition. In particular, while the energy content of the driftwood was comparable to other virgin wood biomass, the uptake of seawater salts worsened the chemical properties of the material, mainly with regards to the chlorine content (about $0.6 \%-2 \%$ ) and the fouling and slagging indexes. However, the washing of driftwood during a rainfall simulation for one month led to a reduction in the chlorine content of about $80 \%-90 \%$. The washing stage had effect also on the major elements content with a positive impact on the fouling and slagging indexes. At the same time, this management strategy implies the production of leachate that should be sent to a wastewater treatment plant to reduce the COD content.

Additional investigation is necessary to build a feasibility study to determine the optimum amount of rainfall water and the storage characteristics necessary to achieve the best driftwood quality, while reducing dry matter losses. Furthermore, future developments of this study will be focused on economic and environmental analysis in order to highlight the sustainability of the bioenergy driftwood chain.

Acknowledgments: The research was partially founded by the Italian Environmental Ministry with an agreement entitled "Recovery and energy valorization of stranded driftwood residues" in 2014-2016.

Author Contributions: Franco Cotana coordinated the work. Cinzia Buratti and Marco Barbanera designed the research and performed preliminary considerations. Andrea Nicolini and Gianluca Cavalaglio provided experimental support and collaborated in the interpretation and analysis of data. Daniele Foschini performed the research, analyzed the data and wrote the paper. Anna Laura Pisello collaborated in writing the paper and revising the manuscript. All authors read and approved the final manuscript.

Conflicts of Interest: The authors declare no conflict of interest. 


\section{References}

1. Mokrech, M.; Kebede, A.S.; Nicholls, R.J.; Wimmer, F.; Feyen, L. An integrated approach for assessing flood impacts due to future climate and socio-economic conditions and the scope of adaptation in Europe. Clim. Chang. 2015, 128, 245-260. [CrossRef]

2. Rech, S.; Macaya-Caquilpan, V.; Pantoja, J.F.; Rivadeneira, M.M.; Jofre Madariaga, D.; Thiel, M. Rivers as a source of marine litter-A study from the SE Pacific. Mar. Pollut. Bull. 2014, 82, 66-75. [CrossRef] [PubMed]

3. Doong, D.-J.; Chuang, H.-C.; Shieh, C.-L.; Hu, J.-H. Quantity, distribution, and impacts of coastal driftwood triggered by a typhoon. Mar. Pollut. Bull. 2011, 62, 1446-1454. [CrossRef] [PubMed]

4. Yamada, H.; Yamauchi, H.; Kurimoto, Y. Color analysis of combustion ashes of seawater-soaked wood: Estimation of salt concentration. J. Mater. Cycles Waste 2014, 16, 576-582. [CrossRef]

5. Grandesso, E.; Gullett, B.; Touati, A.; Tabor, D. Effect of moisture, charge size, and chlorine concentration on PCDD/F emissions from simulated open burning of forest biomass. Environ. Sci. Technol. 2011, 45, 3887-3894. [CrossRef] [PubMed]

6. Schmocker, L.; Hunziker, R.; Müller, U.; Weitbrecht, V. Driftwood Retention in Pre-Alpine Rivers. In Swiss Competences in River Engineering and Restoration; Schleiss, A.J., Speerli, J., Pfammatter, R., Eds.; Taylor \& Francis Group: London, UK, 2014; pp. 117-127.

7. Tsai, W.T.; Tsai, Y.-L.; Liu, S.-C. Utilization of driftwood as an energy source and its environmental and economic benefit analysis in Taiwan. Bioresources 2011, 6, 4781-4789.

8. ANPA. Metodi di Analisi Del Compost. Manuali e Linee Guida 3/2001. Available online: http://www. isprambiente.gov.it/it/pubblicazioni/manuali-e-linee-guida/metodi-di-analisi-del-compost (accessed on 19 January 2016). (In Italian)

9. Italian Organization for Standardization. Solid Biofuels—Determination of Moisture Content_Oven Dry Method, Part 2: Total Moisture—Simplified Method; UNI EN 14774-2:2010; Italian Organization for Standardization: Rome, Italy, 2010.

10. Italian Organization for Standardization. Solid Biofuels—Determination of Ash Content; UNI EN 14775:2010; Italian Organization for Standardization: Rome, Italy, 2010.

11. Italian Organization for Standardization. Solid Biofuels-Determination of Total Content of Carbon, Hydrogen and Nitrose-Instrumental Method; UNI EN 15104:2011; Italian Organization for Standardization: Rome, Italy, 2011.

12. Italian Organization for Standardization. Solid Biofuels, Determination of Calorific Value; UNI EN 14918:2010; Italian Organization for Standardization: Rome, Italy, 2010.

13. European Committee for Standardization. Solid Biofuels-Determination of Major Elements; CEN/TS 15290:2006; European Committee for Standardization: Brussels, Belgium, 2006.

14. German Standardization Organization. Wasserbeschaffenheit_Bestimmung Von Ausgewählten Elementen Durch Induktiv Gekoppelte Plasma-Atom-Emissionsspektrometrie (ICP-OES) (Water Quality-Determination of Selected Elements by Inductively Coupled Plasma Optical Emission Spectroscopy (ICP-OES)); DIN EN ISO 11885:2009-09; German Standardization Organization: Berlin, Germany, 2009.

15. Italian Organization for Standardization. Solid Biofuels-Determination of Total Content of Sulfur and Chlorine; UNI EN 15289:2011; Italian Organization for Standardization: Rome, Italy, 2011.

16. Jenkins, B.M.; Baxter, L.L.; Miles, T.R., Jr; Miles, T.R. Combustion properties of biomass. Fuel Process. Technol. 1998, 54, 17-46. [CrossRef]

17. Liu, Z.; Hoekman, S.K.; Balasubramanian, R.; Zhang, F.S. Improvement of fuel qualities of solid fuel biochars by washing treatment. Fuel Process. Technol. 2015, 134, 130-135. [CrossRef]

18. ISPRA. Procedura di Misurazione Per la Determinazione Della Richiesta Chimica di Ossigeno (COD) Mediante Test in Cuvetta: Metodo 5135, 2014. Available online: http:/ /www.isprambiente.gov.it/files/ pubblicazioni/manuali-lineeguida/MLG_117_14.pdf (accessed on 18 December 2015).

19. Italian Parliament. Decreto Legislativo 3 aprile 2006, n. 152 "Norme in Materia Ambientale”. Available online: http://www.camera.it/parlam/leggi/deleghe/06152dl.htm (accessed on 2 February 2016).

20. Council of European Union. Directive 1999/31/EC on the Landfill of Waste. Available online: http: / /eur-lex.europa.eu/legal-content/EN/TXT/HTML/?uri=CELEX:31999L0031\&from=EN (accessed on 10 February 2016). 
21. Council of European Union. Directive 2008/98/EC on Waste and Repealing Certain Directives. Available online: http:/ / eur-lex.europa.eu/LexUriServ/LexUriServ.do?uri=OJ:L:2008:312:0003:0030:en:PDF (accessed on 10 February 2016).

22. Demirbas, A. Potential applications of renewable energy sources, biomass combustion problems in boiler power systems and combustion related environmental issues. Prog. Energy Combust. Sci. 2005, 31, 171-192. [CrossRef]

23. Gudka, B.; Jones, J.M.; Lea-Langton, A.R.; Williams, A.; Saddawi, A. A review of the mitigation of deposition and emission problems during biomass combustion through washing pre-treatment. J. Energy Inst. 2016, 89, 159-171. [CrossRef]

24. Carrillo, M.A.; Staggenborg, S.A.; Pineda, J.A. Washing sorghum biomass with water to improve its quality for combustion. Fuel 2014, 116, 427-431. [CrossRef]

25. Deng, L.; Zhang, T.; Che, D. Effect of water washing on fuel properties, pyrolysis and combustion characteristics, and ash fusibility of biomass. Fuel Process. Technol. 2013, 106, 712-720. [CrossRef]

26. Jenkins, B.M.; Bakker, R.R.; Wei, J.B. On the properties of washed straw. Biomass Bioenerg. 1996, 10, $177-200$. [CrossRef]

27. Cañedo-Argüelles, M.; Kefford, B.J.; Piscart, C.; Prat, N.; Schäfer, R.B.; Schulz, C.J. Salinisation of rivers: An urgent ecological issue. Environ. Pollut. 2013, 173, 157-167. [CrossRef] [PubMed]

28. Cañedo-Argüelles, M.; Hawkins, C.P.; Kefford, B.J.; Schäfer, R.B.; Dyack, B.J.; Brucet, S.; Buchwalter, D.; Dunlop, J.; Fror, O.; Lazorchak, Y.; et al. Saving freshwater from salts. Science 2016, 351, 914-916. [CrossRef] [PubMed]

(C) 2016 by the authors; licensee MDPI, Basel, Switzerland. This article is an open access article distributed under the terms and conditions of the Creative Commons Attribution (CC-BY) license (http://creativecommons.org/licenses/by/4.0/). 